Vietnam Academy of Science and Technology
Vietnam Journal of Earth Sciences
http://www.vjs.ac.vn/index.php/jse

\title{
Assessment of earthquake-induced ground liquefaction susceptibility for Hanoi city using geological and geomor- phologic characteristics
}

\author{
Bui Thi Nhung ${ }^{* 1}$, Nguyen Hong Phuong ${ }^{1,2}$, Nguyen Ta Nam ${ }^{1}$ \\ ${ }^{1}$ Institute of Geophysics, Vietnam Academy of Science and Technology, 18 Hoang Quoc Viet street, \\ Cau Giay District, Hanoi, Vietnam \\ ${ }^{2} I R D$, Sorbonne Universités, UPMC Univ Paris 06, Unité Mixte Internationale de Modélisation Mathé- \\ matique et Informatiques des Systèmes Complexes (UMMISCO)32 venue Henri Varagnat, 93143 Bondy \\ Cedex, France
}

Received 02 November 2016. Accepted 31 March 2017

\begin{abstract}
In this paper, the earthquake-induced liquefaction susceptibility of Hanoi city is assessed using the recent published geological and geomorphologic data. A combination of classification methods based on the distribution of sedimentary deposits proposed by Youd and Perkins (1978) and geomorphologic units proposed by Iwasaki (1982) was applied. The subsurface lithology and geomorphologic maps were combined in a GIS platform for assessing the liquefaction susceptibility of Hanoi city.

The resulting map shows that the liquefaction hazard of Hanoi city classified into four categories: high, moderate, low liquefaction potential and not likely areas. In the most of Hanoi area, the ground liquefaction potentials are moderate. The high liquefaction likely areas spread along the river beds and around the lake areas. The not likely and low liquefaction potential areas are observed mainly in the northwest and northeast of the study region such as Chan Chim, Soc Son, and Ba Vi mountains. The present map can help the scientists, engineers, and planners to have the general information on regional liquefaction potential of the Hanoi city.
\end{abstract}

Keywords: Liquefaction susceptibility, sedimentary deposits, geomorphology, Hanoi city, GIS.

C2017 Vietnam Academy of Science and Technology

\section{Introduction}

Liquefaction is a soil behavior phenomenon in which a saturated soil loses a substantial amount of strength due to high excess pore-water pressure generated by and accumulated during the strong earthquake $(\mathrm{M} \geq 5.0)$

*Corresponding author, Email: buinhung78@gmail.com ground shaking (Kuribayashi E., et al., 1975; Bird F.J and Bommer J.J., 2004a, 2004b). The direct evidence of this phenomenon is most often observed in saturated, loose (low density or uncompacted), sandy soils (such as Sand boils and lateral spreading), while its indirect evidence can be seen from the response of the constructions (Youd, 1993, Lew et al., 2000). 
Urban areas are most vulnerable to liquefaction hazards, and usually requiring a long time to be recovered after a disaster (Sinha and Goyal 2001). Liquefaction is the main cause of damage to soil structure and other materials which support a construction's life and foundation (Susumu Yasuda, 2000). During the last fifty years, the urban areas, particularly those in the developing countries, while experiencing the explosive development, have been suffering heavy damage and losses from liquefaction and related phenomena.

Hanoi, the capital of Vietnam, is one of the most populated cities of the country. Being situated upon the active Red river - Chay river fault zone, which, according to some geoscientists, is capable of generating earthquakes with maximum magnitude of $\mathrm{M}_{\max }=7.0$ (Phan Trong Trinh et al., 2012, 2013). According to the seismic zoning map of Vietnam published by the Institute of Geophysics, Hanoi belongs to the seismic zone with MSK intensity of VII-VIII (Nguyen Dinh Xuyen, 2008; Nguyen Hong Phuong et al., 2014a, 2014b; Bui Van Duan et al., 2013). Meanwhile, the whole city is based on a sandyclayed sediment of Holocene-Pleistocene age, upon a largely distributed Holocene aquifer (qh) with thickness changing from $0 \mathrm{~m}$ (where the aquifer crops out in the surface) up to 37.5 $\mathrm{m}$, making the average thickness of about 12 $\mathrm{m}$ (Vu Thanh Tam et al., 2014). The downtown districts of Hanoi, with the densest population, highest speed of construction and urban development, are believed to be exposed to high liquefaction risk if an earthquake occurs.

Liquefaction susceptibility of the Old Hanoi city has been assessed by Nguyen Hong Phuong et al., (2002, 2007, 2013, 2014a), using the methodology proposed by Youd and Perkins (1978). In this paper, we present the results of the assessment of earthquake-induced liquefaction hazard for the expanded Hanoi city using methods which allow combining geological and geomorphologic characteristics.

\section{Data and methods}

\subsection{Geological and Engineering-geological data}

In order to get information on geological characteristics to be used in the assessment of the liquefaction of the Hanoi region, the previously published researches on geology of Hanoi has been collected and analyzed (Geological map of Hanoi, General Department of Geology and Minerals of Vietnam, 2005; Vu Thanh Tam et al., 2014) and the EngineeringGeological map of Hanoi in scale of 1: 25,000 by Ngo Quang Toan et al., 2015 (Figure 1).

According to the published data, Hanoi is founded in the crystalline basement of Neoproterozoic-Lower Cambric age (NP- $\mathrm{C}$ ), covered by the formations of Mesozoic, Neogenic and Quaternary ages.

Within the boundary of Hanoi city, there are 11 different stratigraphic units having ages from Neoproterozoic to Kainozoic distributed with the total thickness of over $3600 \mathrm{~m}$. The petrographic setting comprises formations of marine, terrigenous, volcanic terrigenous, volcanic, artificial, ruins, river, lake, and marshy origins. There are 6 Pre-Quaternary stratigraphic units not cropping out in the study area, including the Chay river (NP-e sc), the Khon Lang $\left(\mathrm{T}_{2} \mathrm{a} \mathrm{kl}\right)$, the Na Khuat $\left(\mathrm{T}_{2} \mathrm{nk}\right)$, the Ha Coi $\left(\mathrm{J}_{1-2} \mathrm{hc}\right)$, the Tam Lung $\left(\mathrm{J}_{3}-\mathrm{K}_{1} \mathrm{tl}\right)$ and the Vinh Bao $\left(\mathrm{N}_{2} \mathrm{vb}\right)$. The outcrop 5 Quaternary stratigraphic units are described below:

The Lower Pleistocene sediment of the Le Chi formation $\left(a Q^{l} l c\right)$ is distributed at the depth from $-45 \mathrm{~m}$ to about $-70 \div-80 \mathrm{~m}$, which lies upon the Pliocene sediment. The thickness of the formation is changing from $2.5 \mathrm{~m}$ to $24.5 \mathrm{~m}$.

The Middle and Upper Pleistocene sediment of the Hanoi formation $\left(a Q^{2-3} h n\right)$ is widely distributed in the Hanoi region at the 
depth from $-33.0 \div-78.0 \mathrm{~m}$, with the thickness changing from $33.0 \mathrm{~m}$ to $40.0 \mathrm{~m}$.

The Upper Pleistocene sediment of the Vinh Phuc formation $\left(a Q^{3} v p\right)$ crops out in the surface in the northern part of Hanoi region, including majority of Dong Anh district, a part of Soc Son district and another small part of Co Nhue commune, Xuan Dinh, with the thickness changing from $9.0 \mathrm{~m}$ to $23.5 \mathrm{~m}$. Based on the petrographic content, the formation can be di- vided into two members: the lower member $\left(a Q^{3} v p_{1}\right)$ comprises pebble, powder containing granule, yellowish-grey clay with the thickness changing from 4.0 to $13.5 \mathrm{~m}$, and the upper member $\left(a Q^{3} v p_{2}\right)$ comprises clayey sand, silty sand, brown to reddish variegated clay sediments containing plant detritus and peat of different origins, such as lake, swamps, marine with total thickness changing from 5.0 to $10.0 \mathrm{~m}$.

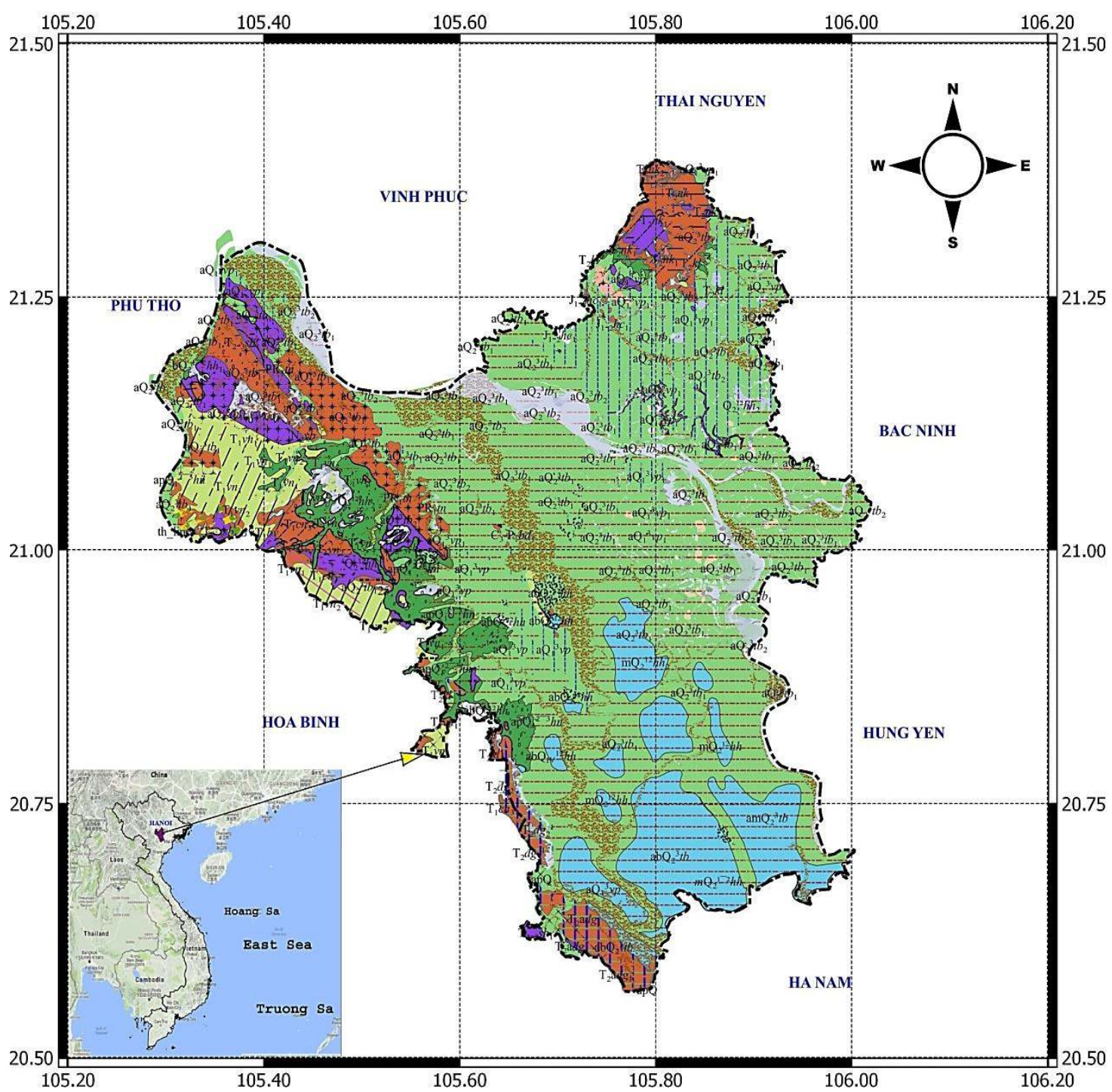

Figure 1. Distribution of sediment deposits in the Hanoi region (Ngo Quang Toan, 2015; Vu Thanh Tam, 2014) 
Bui Thi Nhung, et al./Vietnam Journal of Earth Sciences 39 (2017)

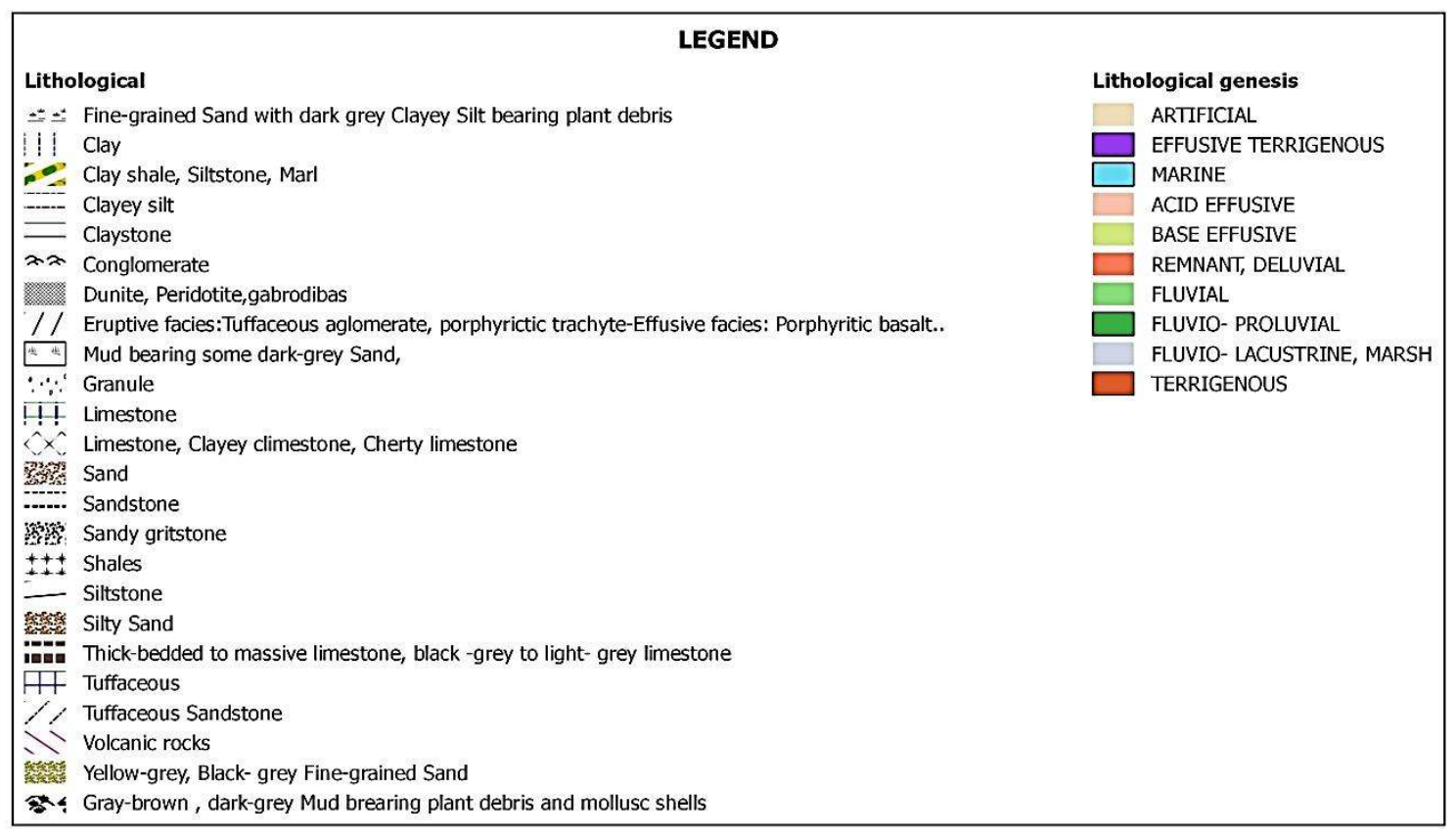

The Upper Pleistocene sediment of the Hai Hung formation $\left(\mathrm{aQ}^{3} h h\right)$ is widely distributed in the Hanoi region, but mostly covered by the Holocene series, with the thickness ranking between 9 to $24 \mathrm{~m}$, and the average thickness is $18.5 \mathrm{~m}$. In fact, this is a transitional layer between the Pleistocene and the Holocene sediments, which also plays the role of a water resistant boundary between the Pleistocene and the Holocene aquifers.

The Holocene sediment of the Thai Binh formation $(\mathrm{Q} t b)$ is cropping out in the southern part of the Red river within the boundary of Hanoi city. The thickness of this layer changes from 0 to $26.0 \mathrm{~m}$, the average thickness is $6.15 \mathrm{~m}$. According to the petrographic content, this formation can be divided into two members: the lower member comprises pebble, sand, silty sand mixed with clay with the thickness changing from 1.0 to $9.0 \mathrm{~m}$, and the upper member comprises brown silty sand, clayey silt, sandy clay mixed with plant detritus, with the thickness changing from 3 to $19.0 \mathrm{~m}$ (General Department of Geology and Minerals of Vietnam, 2005; Vu Thanh Tam et al., 2014, Ngo Quang Toan, 2015).

\subsection{Geomorphologic data}

Geomorphological information the Hanoi region is taken from the geo-morphologic map of Hanoi region by Dao Dinh Bac et al., 2010 (Figure 2). The geo-morphologic characteristics of the Hanoi region can be described as follows:

The first feature is that Hanoi is located at the center of a low plain, the southern part of which is having deltaic plain features, and the northern part is having the lower course river plain features.

In the entire large and plain region, the relatively high elevation terraces of Pleistocene age can always be found in the northern, northeastern and western margins. The second high elevation type, which is lower than the latter and more complicatedly distributed are the riverbeds bounded high edges, sometimes creating the natural dams, quite common at the rivers crossings like the Red river and Nhue river junction, or the high edges bounding the present Red river and outside the Hoan Kiem lake, or the larger highland along the ancient Red river near the West lake. 
The second topographic element here is the low depression area in the center of the region, which before the appearance of the dam system have usually been accreted by a smooth alluvial layer during flooding seasons, and also served as a drainage to let the flood water out from the West lake to the southeastern direction. That is the reason why in the western and southern areas of the Old Thang Long - Hanoi nowadays exit so many lakes, and coupled with branches of the Nhue and To Lich rivers exit the long flood drainage channels, known as the $\mathrm{Lu}$ and Set rivers.

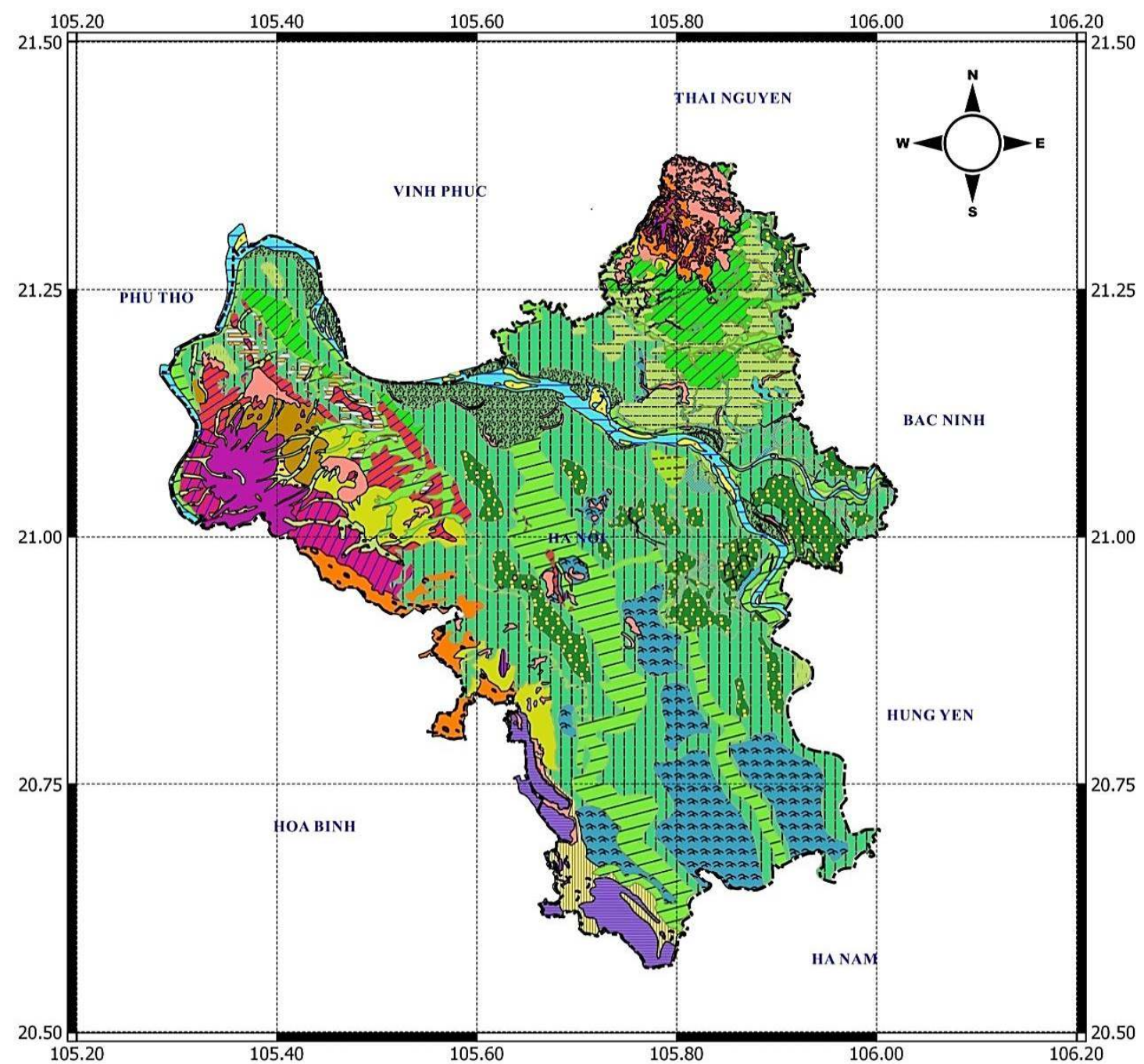

Figure 2. Geomorphologic distribution of the Hanoi region (Dao Dinh Bac, 2010) 


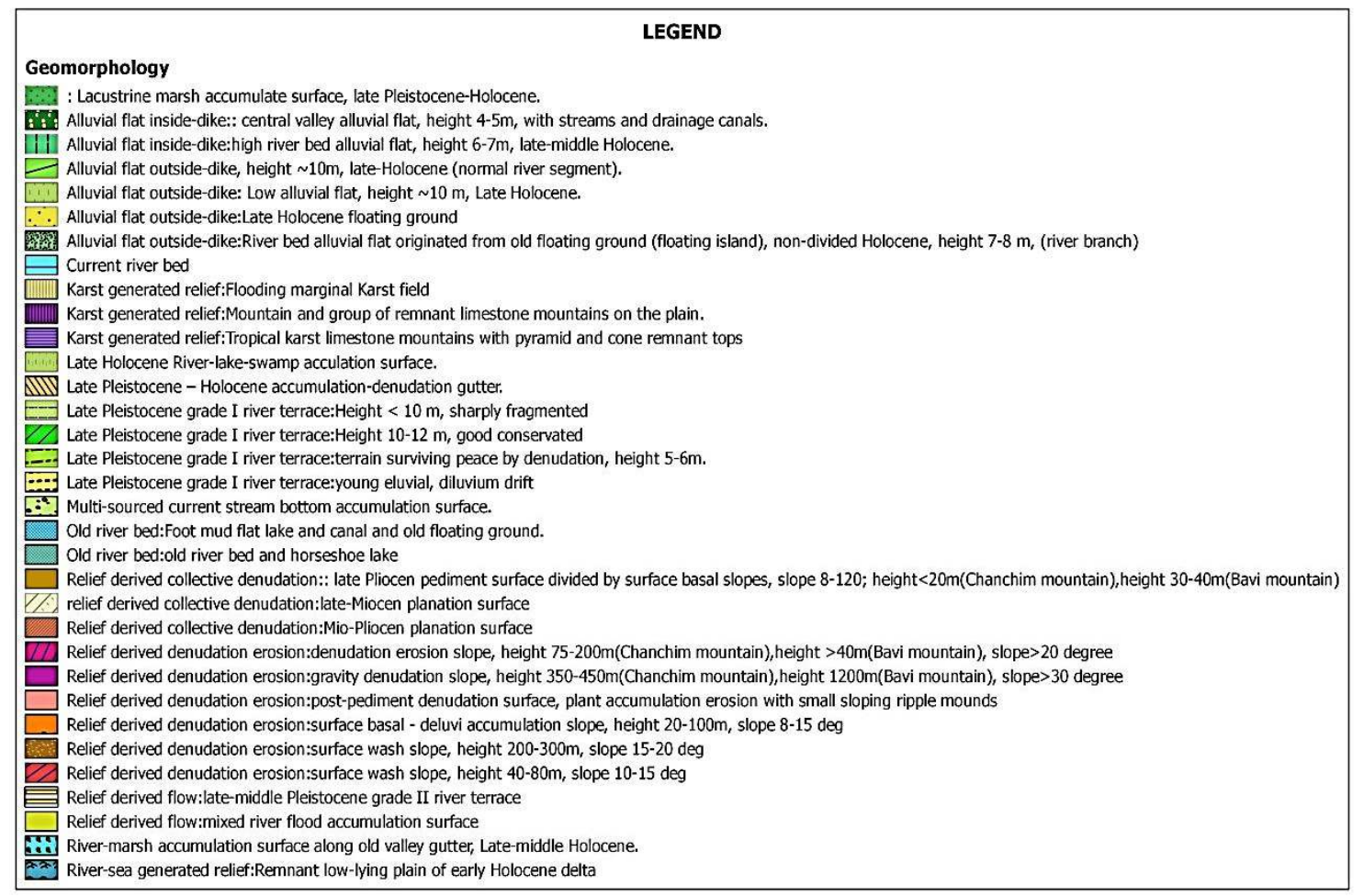

The distribution of the Pleistocene terrace $1\left(\mathrm{Q}_{I}{ }^{3} v p\right)$ suggests the opening tendency to the east and southeast directions of the Red river bed. During the creation period of this terrace, the Day river's mouth was the mouth of Red river (the terrace 1 was located on two sides of the Day river bed). Then, during the Upper Holocene $\left(\mathrm{Q}_{2}{ }^{3}\right)$, the Red river stream abruptly crossed its terrace 1 , rushing eastward through the Hanoi area to go southward subjected to the dynamics of the neotectonic regime (after a long period of moving to the northeastern and eastern directions, the Red river bed was finally fit into the central graben, while a branch of the Duong river flows steadily to the present lower settlement (named Luc Dau Giang). In addition, the appearance of the remained abrasive or dam mudflats around the Imperial Citadel of Thang Long allow to determine the places with stable engineering-geological contents.
The second feature is that Hanoi is clamped between the two highlands distributed symmetrically with each other crossing the Red river, with transformation from the absolute subsidence of the central plain to the slight uplift of the denudated hill-shape surface and the pediment in the midland, followed by tectonic blocks with an uplift amplitude such as $\mathrm{Ba}$ Vi and Tam Dao.

The third feature is that the high elevated alluvial terraces and the ancient pediment in the northern part of Hanoi are degraded due to long erosion and washout period, now having a solid foundation and no longer affected by the Red river's flooding waters.

In addition, in Hanoi region there are many places where the remained ancient river beds, lakes and swamps now are affected by human activities and replaced by urban areas.

\subsection{Methods}

Youd and Hoose (1977) when analyzing 
the information on 21 earthquakes recorded worldwide within the period from 1811 to 1976 have concluded that the liquefaction susceptibility is related to geological characteristics. Using this result and some additional data, Youd and Perkins (1978) have addressed the liquefaction susceptibility of various types of soil deposits by assigning a qualitative susceptibility rating based upon general depositional environment and geologic age of the deposit. The relative susceptibility ratings of Youd and Perkins (1978) shown in Table 1 indicate that recently deposited relatively unconsolidated soils such as Holocene-age river channel, floodplain, and delta deposits and uncompacted artificial fills located below the groundwater table have high to very high liquefaction susceptibility. Sands and silty sands are particularly susceptible to liquefaction. Silts and gravels also are susceptible to liquefaction, and some sensitive clays have exhibited liquefaction-type strength losses (Updike, et. al., 1988). Such deposits as an alluvial fan and plain, beach, high wave energy, glacial till, talus, residual soils, tuff and compacted fill in general not susceptible to liquefaction.

For each deposit type, the liquefaction susceptibility is decreasing by the ages, from young $(<500$ years) to old (Pre-Pleistocene), except for the loess, which is always susceptible to liquefaction during strong earthquakes no matter the age is of Holocene or Pleistocene. The Holocene sediments are more susceptible to liquefaction than the Pleistocene ones, and the Pre-Pleistocene sediments are rarely liquefied.

Iwasaki et al. (1982) proposed another approach based on the relationship between liquefaction events and the geomorphologic characteristic of the place where the liquefaction occurred. The data published by Kuribayashi and Tatsuoka (1975) was used in- cluding 44 liquefaction caused earthquakes recorded in Japan during a 96 year period since 1872 (with magnitudes $\mathrm{M}=5.2 \div 8.2$ ) referencing to the certain geomorphologic conditions. The results show that the earthquake-triggered liquefactions mostly occurred in alluvial sandy sediments, especially in the reclamation areas, river beds or present lakes. The authors proposed a set of criteria for micro-zoning of liquefaction susceptibility based on the geomorphologic information as shown in Table 2. As can be seen from Table 2, the high possibility of liquefaction is concentrated in the places as the present river- or lake beds, ancient riverbeds, swamps, reformed lands or lowlands in sand dunes. The medium liquefaction susceptibility is assigned for such structures as the fan, floodplain, other plains or natural dams. The rocky mountains are not susceptible to liquefaction, and in general, the rocky areas or areas with bedrocks are considered not subject to liquefaction.

\section{Results and disscusion}

\subsection{Asessment of liquefaction susceptibility of the Hanoi region based on the geological characteristics}

Using the information on geologic age, soil/geologic conditions of the Hanoi region, petrographic types taken from the engineering-geologic map of Hanoi (Figure 1), the relative susceptibility ratings according to Youd and Perkins (1978) shown in Table 1 was applied to each geological unit by assigning the weighting values as shown in Table 3, where the weighting values rank from 1 to 4 , indicating the increasing level of liquefaction susceptibility. The results obtained from table 3 then were used in a GIS platform to compile a thematic map showing the distribution of liquefaction susceptibility of the Hanoi region based on the geological characteristics (Figure 3). 
Bui Thi Nhung, et al./Vietnam Journal of Earth Sciences 39 (2017)

Table 1. Liquefaction Susceptibility of Sedimentary Deposits (from Youd and Perkins, 1978)

\begin{tabular}{|c|c|c|c|c|c|}
\hline \multirow{2}{*}{ Type of Deposit } & \multirow{2}{*}{$\begin{array}{c}\text { General } \\
\text { Distribution of } \\
\text { Cohesionless } \\
\text { Sediments in } \\
\text { Deposits }\end{array}$} & \multicolumn{4}{|c|}{$\begin{array}{l}\text { Likelihood that Cohesionless Sediments when } \\
\text { Saturated would be Susceptible to Liquefaction (by Age of Deposit) }\end{array}$} \\
\hline & & $\begin{array}{l}<500 \mathrm{yr} \\
\text { Modern }\end{array}$ & $\begin{array}{l}\text { Holocene } \\
<11 \mathrm{ka}\end{array}$ & $\begin{array}{l}\text { Pleistocene } \\
11 \mathrm{ka}-2 \mathrm{Ma}\end{array}$ & $\begin{array}{l}\text { Pre-Pleistocene } \\
>2 \mathrm{Ma}\end{array}$ \\
\hline & & \multicolumn{4}{|c|}{ (a) Continental Deposits } \\
\hline River channel & Locally variable & Very High & High & Low & Very Low \\
\hline Flood plain & Locally variable & High & Moderate & Low & Very Low \\
\hline Alluvial fan and plain & Widespread & Moderate & Low & Low & Very Low \\
\hline $\begin{array}{l}\text { Marine terraces and } \\
\text { plains }\end{array}$ & Widespread & --- & Low & Very Low & Very Low \\
\hline Delta and fan-delta & Widespread & High & Moderate & Low & Very Low \\
\hline Lacustrine and playa & Variable & High & Moderate & Low & Very Low \\
\hline Colluvium & Variable & High & Moderate & Low & Very Low \\
\hline Talus & Widespread & Low & Low & Very Low & Very Low \\
\hline Dunes & Widespread & High & Moderate & Low & Very Low \\
\hline Loess & Variable & High & High & High & Unknown \\
\hline Glacial till & Variable & Low & Low & Very Low & Very Low \\
\hline Tuff & Rare & Low & Low & Very Low & Very Low \\
\hline Tephra & Widespread & High & High & $?$ & $?$ \\
\hline Residual soils & Rare & Low & Low & Very Low & Very Low \\
\hline Sebka & Locally variable & High & Moderate & Low & Very Low \\
\hline & & (b) Coa & Zone & & \\
\hline Delta & Widespread & Very High & High & Low & Very Low \\
\hline Esturine & Locally variable & High & Moderate & Low & Very Low \\
\hline \multicolumn{6}{|l|}{ Beach } \\
\hline High Wave Energy & Widespread & Moderate & Low & Very Low & Very Low \\
\hline Low Wave Energy & Widespread & High & Moderate & Low & Very Low \\
\hline Lagoonal & Locally variable & High & Moderate & Low & Very Low \\
\hline Fore shore & Locally variable & High & Moderate & Low. & Very Low \\
\hline \multicolumn{6}{|c|}{ (c) Artificial } \\
\hline Uncompacted Fill & Variable & Very High & -- & - & -- \\
\hline Compacted Fill & Variable & Low & --- & --- & --- \\
\hline
\end{tabular}

Table 2. Liquefaction Susceptibility of geomorphologic units (Iwasaki, 1982)

\begin{tabular}{|c|c|c|}
\hline Rank & Geomorphologic units & Liquefaction susceptibility \\
\hline A & Present river bed, old river bed, swamp, reclaimed land and inter-dune lowland & Liquefaction likely \\
\hline B & Fan, natural levee, sand dune, flood plain, beach and other plains & Liquefaction possibly \\
\hline $\mathrm{C}$ & Terrace, hill and mountain & Liquefaction not likely \\
\hline
\end{tabular}


Vietnam Journal of Earth Sciences 39(2), 139-154

Table 3. Liquefaction susceptibility of sedimentary deposits defined in the Hanoi city

\begin{tabular}{|c|c|c|c|}
\hline Lithological genesis & Geologic age & Sediment description & Classification** $*^{*}$ \\
\hline \multirow{14}{*}{ Terrigeno-us } & $\mathrm{T}_{2} d g_{2}$ & \multirow{3}{*}{ Limestone } & \multirow{7}{*}{1} \\
\hline & $\mathrm{T}_{2} a d g_{2}^{2}$ & & \\
\hline & $\mathrm{T}_{2} \mathrm{adg}_{1}$ & & \\
\hline & $\mathrm{T}_{2} \mathrm{nk}_{2}$ & Conglomerate & \\
\hline & $\mathrm{T}_{2} \mathrm{nk}_{1}$ & Claystone & \\
\hline & $\mathrm{T}_{2} \mathrm{dg}$ & Sandy gritstone & \\
\hline & $\mathrm{J}_{12} \mathrm{hc}_{1}$ & Shales, granule, gritstone & \\
\hline & \multirow{2}{*}{$\mathrm{PR}_{3} \in \mathrm{tk}_{3}$} & Shales & 1 \\
\hline & & Clayey silt & 1 \\
\hline & PRitn & Shales, Sandy gritstone & 1 \\
\hline & $\mathrm{P}_{2} v \mathrm{~d}$ & Eruptive facies, Shales, Sandy gritstone & 1 \\
\hline & \multirow{2}{*}{$\mathrm{T}_{1} \mathrm{cn}_{3}$} & Volcanic rocks, limestone & \multirow{2}{*}{1} \\
\hline & & Sandy gritstone, conglomerate & \\
\hline & $\sigma v \mathrm{~T}_{1} b v$ & $\begin{array}{l}\text { Clay shales, siltstone, marl, Dunite, Peridotite, } \\
\text { gabrodibas }\end{array}$ & 1 \\
\hline \multirow{6}{*}{ Effusive Terrigenous } & \multirow{3}{*}{$\mathrm{T}_{2} \mathrm{kl}$} & Tuffaceous sandstone & \multirow{3}{*}{1} \\
\hline & & Limestone & \\
\hline & & Shales & \\
\hline & \multirow{3}{*}{$\mathrm{T}_{23} \mathrm{sb}_{1}$} & Shales, limestone & \multirow{2}{*}{1} \\
\hline & & Siltstone, sandstone & \\
\hline & & Clayey silt & 1 \\
\hline \multirow{4}{*}{ Base eruption } & \multirow{3}{*}{$\mathrm{T}_{1} \mathrm{vn}_{2}$} & Clay, Clayey silt & 1 \\
\hline & & Shales, volcanic rocks, limestone & \multirow{3}{*}{1} \\
\hline & & Sandstone, Sandy gritstone, conglomerate & \\
\hline & $\mathrm{T}_{1} \mathrm{vn}_{1}$ & Tuffaceous & \\
\hline \multirow{2}{*}{ Acid eruption } & \multirow{2}{*}{$\mathrm{J}_{3}-\mathrm{K}_{1} \mathrm{tl}$} & Siltstone & \multirow{2}{*}{1} \\
\hline & & Porphyrictic trachyte, rhyolite, Shales & \\
\hline \multirow{2}{*}{ Artificial } & & Compacted Fill & 1 \\
\hline & & Uncompacted Fill & 4 \\
\hline \multirow{4}{*}{ Marine } & \multirow{2}{*}{$\mathrm{Q}_{2}{ }^{12} \mathrm{hh}_{2}$} & Silty Sand, Clayey silt & 3 \\
\hline & & Shales, granule, sandy gritstone & 2 \\
\hline & $\mathrm{mQ}_{2}{ }^{12} \mathrm{hh}$ & & \\
\hline & $\mathrm{amQ}_{2}{ }^{3} \mathrm{tb}$ & Clayey silt & 3 \\
\hline \multirow{6}{*}{ Fluvial } & $\mathrm{abQ}_{2}{ }^{12} \mathrm{hh}$ & Sandy mixed grit & 3 \\
\hline & $\mathrm{aQ}_{1}{ }^{3} \mathrm{vp}$ & Clay & 3 \\
\hline & $\mathrm{aQ}_{2}{ }^{3} \mathrm{tb}_{1}$ & Silty Sand, Clayey silt & 3 \\
\hline & \multirow[b]{2}{*}{$\mathrm{aQ}_{2}{ }^{3} \mathrm{tb}_{2}$} & Clay, Silty Sand, Clayey silt & 3 \\
\hline & & $\begin{array}{l}\text { Yellow-grey, black-grey fine-grained Sand with re- } \\
\text { mains of plant and mollusc shell }\end{array}$ & 4 \\
\hline & $\mathrm{aQ}_{1}{ }^{3} \mathrm{vp}_{1}$ & Clay, Silty Sand, Clayey silt & 3 \\
\hline \multirow{2}{*}{ Fluvio-Proluvial } & $\mathrm{apQ}^{1^{2-3} \mathrm{hn}}$ & Granule, claystone & 2 \\
\hline & $\mathrm{aQ}_{2}{ }^{3} \mathrm{tb}_{1}$ & Clayey silt, Silty Sand & 3 \\
\hline \multirow{3}{*}{ Fluvio-lacustrine, swamp } & $\mathrm{albQ}_{2}{ }^{3} \mathrm{tb}$ & $\begin{array}{l}\text { Brownish grey mud, Blackish grey mud brearing } \\
\text { plant debris and mollusc shell }\end{array}$ & \multirow{2}{*}{4} \\
\hline & $\mathrm{lbQ}_{2}{ }^{12} \mathrm{hh}$ & $\begin{array}{l}\text { Mud with blackish grey sand, Fine-grained Sand with } \\
\text { dark grey clayey silt bearing plant debris }\end{array}$ & \\
\hline & $\mathrm{lbQ}_{1}{ }^{3} \mathrm{vp}$ & $\begin{array}{l}\text { Clayey, sandy soil, kaolin clay, clay with blackish } \\
\text { grey flora humus }\end{array}$ & 3 \\
\hline
\end{tabular}

${ }^{* *}$ Note: 1- Non-Liquefiable, 2- Low susceptibility to liquefaction, 3- Moderate susceptibility to liquefaction, 4- High susceptibility to liquefaction 
As can be seen from Figure 3, based on the geological characteristics, the majority of Hanoi's territory has moderate liquefaction susceptibility. The highest susceptibility to liquefaction can be found in the lowland plain, where the whole area is subsided 5-6 $\mathrm{m}$ and divided by a complicated system of rivers, channels, lakes and ponds. The area is characterized by sediments of river-lake and swamp origin $\left(\mathrm{albQ}_{2}{ }^{3} \mathrm{tb}\right)$, with narrow distribution found in Dong Anh and some downtown places, the young sediments $\left(\mathrm{aQ}_{2}{ }^{3} \mathrm{tb}\right)$ distributed along the Red river and Duong river beds. The main contents of these sediments are gray to dark gray biopelite sandy and clayish silts, mixed with plant detritus. The other sediments are of the lake-swamp origin $\left(\mathrm{lbQ}_{2}{ }^{1-2} \mathrm{hh}\right)$ distributed at the 1.5 to $20 \mathrm{~m}$ depth from the surface, with the average thickness of $13.5 \mathrm{~m}$ comprise greenish grey to dark grey biopelite sandy and clayish silts, mixed with plant detritus are also largely distributed in the downtown area and in the Thanh Tri district.

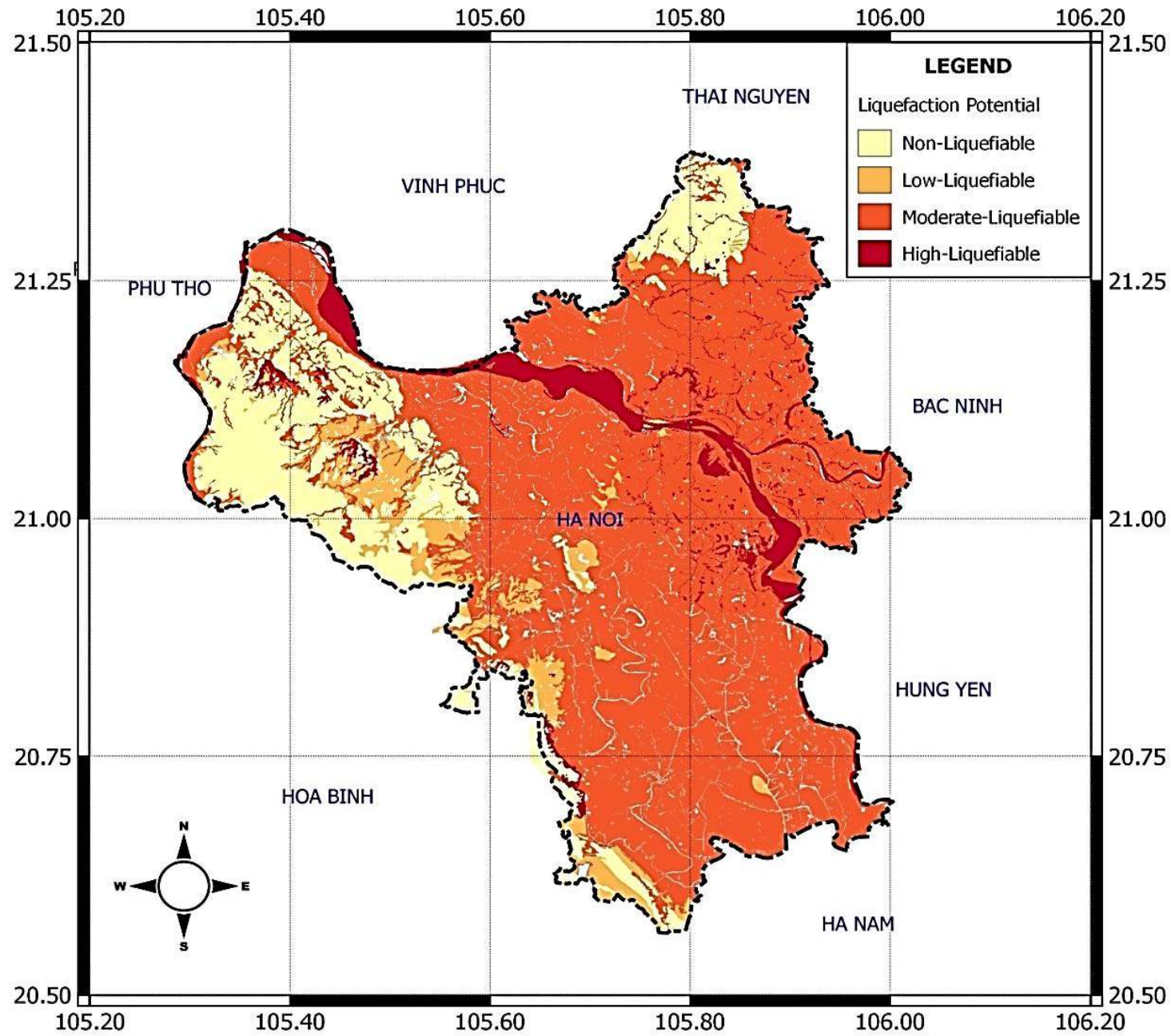

Figure 3. Map of liquefaction susceptibility of Hanoi city obtained from the Youd and Perkins (1978) method 
The moderate liquefaction susceptibility zone occupies the flat plain area distributed in two sides of the Red river bank, with complicated geological structure comprises the Holocene sediments of marine and river origins, for example the $\left(\mathrm{Q}_{2}{ }^{1-2} \mathrm{hh}\right)$ sediments, widely distributed in downtown Hanoi, the Tu Liem and Thanh Tri Districts, with thickness changing between 0.4 to $4 \mathrm{~m}$, average thickness of $1.5 \mathrm{~m}$, and comprise silty clay mixed with sand. The other are the $\left(\mathrm{Q}_{2}{ }^{3} \mathrm{tb}, \mathrm{Q}_{1}{ }^{3} \mathrm{vp}\right)$ sediments, comprise mainly yellowish gray silty clay, sand, and sandy silt, mixed with the pebble, underlay by plastic pebble mixed with clay, clayey sand bearing plant remains, distributed widely in the Hanoi region. The mountain area located in the northern and southwestern parts of the city and the Soc Son mountain in the north, which comprise hard schists, are not liquefiable.

\subsection{Assessment of liquefaction susceptibility of the Hanoi region based on the geomor- phological characteristics}

Using the geomorphologic map of the Hanoi region (Figure 2), the susceptibility standards according to Iwasaki (1982) shown in Table 2 was applied to each geomorphologic unit by assigning the weighting values as described in the previous section, where the weighting values rank from 1 to 4 , indicating the increasing level of liquefaction susceptibility. The results obtained are shown in table 4 and then were used to compile a thematic map showing the distribution of liquefaction susceptibility of the Hanoi region in a GIS environment (Figure 4).

As can be seen from Figure 4, according to the geomorphologic characteristics, the majority of Hanoi's territory has moderate liquefac- tion susceptibility. It should be noted that, for the geomorphologic case (Figure 4), the zone with high susceptibility to liquefaction are larger in compare with the corresponding zone in the geological case (Figure 3). Beside the rivers, lakes and swamps areas, which are the same in both cases, in Figure 4 the outside dam mudflats, low mudflats and the accumulative surface of the present streams have been added to the high liquefaction susceptibility zone that stretching from northern to southern parts of Hanoi, including the whole Thanh Tri and Gia Lam districts. In addition, in Figure 4, the zone with low susceptibility to liquefaction, which distributed mainly in the northeastern and northwestern parts of the city are expanded in a narrow belt along the western boundary of the city, while the northeastern area is also enlarged to the south, occupying most of the Soc Son district. The zone comprises the limestone mountains, hard shales, the highlands of the alluvial terraces, degraded ancient pediment due to a long process of erosion and washout, which have the solid foundation.

\subsection{Asessment of liquefaction susceptibility of the Hanoi region based on the geological and geomorphological characteristics}

As discussed by some authors, the sedimentary deposits play the main role in liquefaction susceptibility of a certain region (Ganapathy Pattukandan Ganapathy, Ajay S. Rajawat, 2012). In this study, the petrographic units in the map on Figure 3 and the geomorphologic units in the map in Figure 4 were assigned the weight values of $60 \%$ and $40 \%$, respectively and were integrated into a map of liquefaction susceptibility of Hanoi city, shown in Figure 5. 
Bui Thi Nhung, et al./Vietnam Journal of Earth Sciences 39 (2017)

Table 4. Liquefaction susceptibility of the geomorphologic units defined in the Hanoi city

\begin{tabular}{|c|c|c|}
\hline Type of relief & Geomorphologic units & Classification $^{* * *}$ \\
\hline \multirow[b]{3}{*}{$\begin{array}{l}\text { I. Collective denudation } \\
\text { relief }\end{array}$} & Late Miocene plain surface & \multirow[b]{3}{*}{1} \\
\hline & Miocene-Pliocene plain surface & \\
\hline & $\begin{array}{l}\text { Late Pliocene Pediment surface divided by surface washed slopes, slope } \\
\text { angle } 8-12^{\circ} \text {; height }<20 \mathrm{~m} \text { (the Chan Chim mountain), 33-40 } \mathrm{m} \text { height } \\
\text { (the } \mathrm{Ba} \mathrm{Vi} \text { mountain). }\end{array}$ & \\
\hline \multirow{6}{*}{$\begin{array}{l}\text { II. Erosional denudation } \\
\text { relief }\end{array}$} & $\begin{array}{l}\text { Gravitational denudation slopes, } 350-450 \mathrm{~m} \text { height (the ChanChim moun- } \\
\text { tain) and up to } 1200 \mathrm{~m} \text { (the Ba Vi mountain), slope angle }>30 \text { degrees. }\end{array}$ & \multirow{6}{*}{1} \\
\hline & $\begin{array}{l}\text { Erosional denudative slopes, } 75-200 \mathrm{~m} \text { height (the ChanChim mountain) } \\
\text { and height }>40 \mathrm{~m} \text { (the Ba Vi mountain), slope angle }>20^{\circ}\end{array}$ & \\
\hline & $\begin{array}{l}\text { Surface washed slopes - deluvian accumulative slopes, } 20-100 \mathrm{~m} \text { height, } \\
\text { slope angle } 8-15^{\circ} \text {. }\end{array}$ & \\
\hline & Surface washed slopes, $200-300 \mathrm{~m}$ height, slope angle $15-20^{\circ}$. & \\
\hline & Surface washed slopes, $40-80 \mathrm{~m}$ height, slope angle $10-15^{\circ}$. & \\
\hline & $\begin{array}{l}\text { Post-pediment denudation surface, erosional - accumulative surface, with } \\
\text { small ripple mounds. }\end{array}$ & \\
\hline \multirow{17}{*}{ III. Flow-generated relief } & Mixed river flood accumulation surface, $\mathrm{Q}_{1}{ }^{2-1}$ age. & \multirow{2}{*}{1} \\
\hline & Late-middle Pleistocene grade II river terrace, $\mathrm{Q}_{1}{ }^{2-1}$ age. & \\
\hline & $\begin{array}{l}\text { Late-middle Pleistocene grade I river terrace, } \mathrm{Q}_{1}{ }^{1} \text { age. } 12-14 \mathrm{~m} \text { height, } \\
\text { well preserved. Height }<10 \mathrm{~m} \text {, strongly fragmented. Denudation remain of } \\
5-6 \mathrm{~m} \text { height. Young eluvial, diluvium drift of } \mathrm{Q}_{2}{ }^{3} \text { age. }\end{array}$ & 2 \\
\hline & $\begin{array}{l}\text { Inside-dike alluvial flat, high river bed alluvial flat, height } 6-7 \mathrm{~m} \text {, } \\
\text { late-middle Holocene age. (Ba vi area }>10 \mathrm{~m}\end{array}$ & 3 \\
\hline & $\begin{array}{l}\text { Inside-dike alluvial flat, valley alluvial flat, } 4-5 \mathrm{~m} \text { height, with streams } \\
\text { and drainage canals. }\end{array}$ & \multirow{3}{*}{4} \\
\hline & $\begin{array}{l}\text { Ouside-dike alluvial flat, } \sim 10 \mathrm{~m} \text { height, Late Holocene age (normal river } \\
\text { segment). }\end{array}$ & \\
\hline & $\begin{array}{l}\text { Ouside-dike alluvial flat, low alluvial flat, } 7-8 \mathrm{~m} \text { height (normal river } \\
\text { segment) }\end{array}$ & \\
\hline & $\begin{array}{l}\text { Ouside-dike alluvial flat, river bed alluvial flat originated from old float- } \\
\text { ing ground (floating islands), non-divided Holocene age, } 7-8 \mathrm{~m} \text { height, } \\
\text { (river branch) }\end{array}$ & \multirow[t]{2}{*}{4} \\
\hline & Ouside-dike alluvial flat, Late Holocene floating ground. & \\
\hline & Old river bed and horseshoe-shape lake & \multirow{3}{*}{4} \\
\hline & $\begin{array}{l}\text { Old river bed, Holocene age foot mud flat lake, canal and old floating } \\
\text { ground. }\end{array}$ & \\
\hline & Present river bed. & \\
\hline & Accumulation-denudation gutter. & 2 \\
\hline & Late Pleistocene-Holocene Lacustrine marsh accumulate surface, $\mathrm{Q}_{1}{ }^{2}-\mathrm{Q}_{2}$ & 3 \\
\hline & $\begin{array}{l}\text { River-marsh accumulation surface along old valley gutter, Late-middle } \\
\text { Holocene age } \mathrm{Q}_{2}^{2-1} \text {. }\end{array}$ & \multirow{3}{*}{4} \\
\hline & Late Holocene River-lake-swamp acculation surface $\mathrm{Q}_{2}{ }^{3}$. & \\
\hline & Multi-sourced current stream bottom accumulation surface. & \\
\hline $\begin{array}{l}\text { IV. Marine-river- } \\
\text { generated relief }\end{array}$ & $\begin{array}{l}\text { Marine-river-generated relief. Remnant low-lying plain of early Holocene } \\
\text { delta } \mathrm{Q}_{2}^{2-1}\end{array}$ & 3 \\
\hline \multirow{3}{*}{$\begin{array}{l}\text { V. Karst- generated } \\
\text { relief }\end{array}$} & $\begin{array}{l}\text { Karst- generated relief. Tropical karst limestone mountains with pyramid } \\
\text { and cone remnant tops. }\end{array}$ & \multirow[t]{2}{*}{1} \\
\hline & Mountain and group of remnant limestone mountains on the plain. & \\
\hline & Flooding marginal Karst field & 2 \\
\hline
\end{tabular}

${ }^{* * *}$ Note: 1- Non-Liquefiable, 2- Low susceptibility to liquefaction, 3- Moderate susceptibility to liquefaction, 4- High susceptibility to liquefaction 


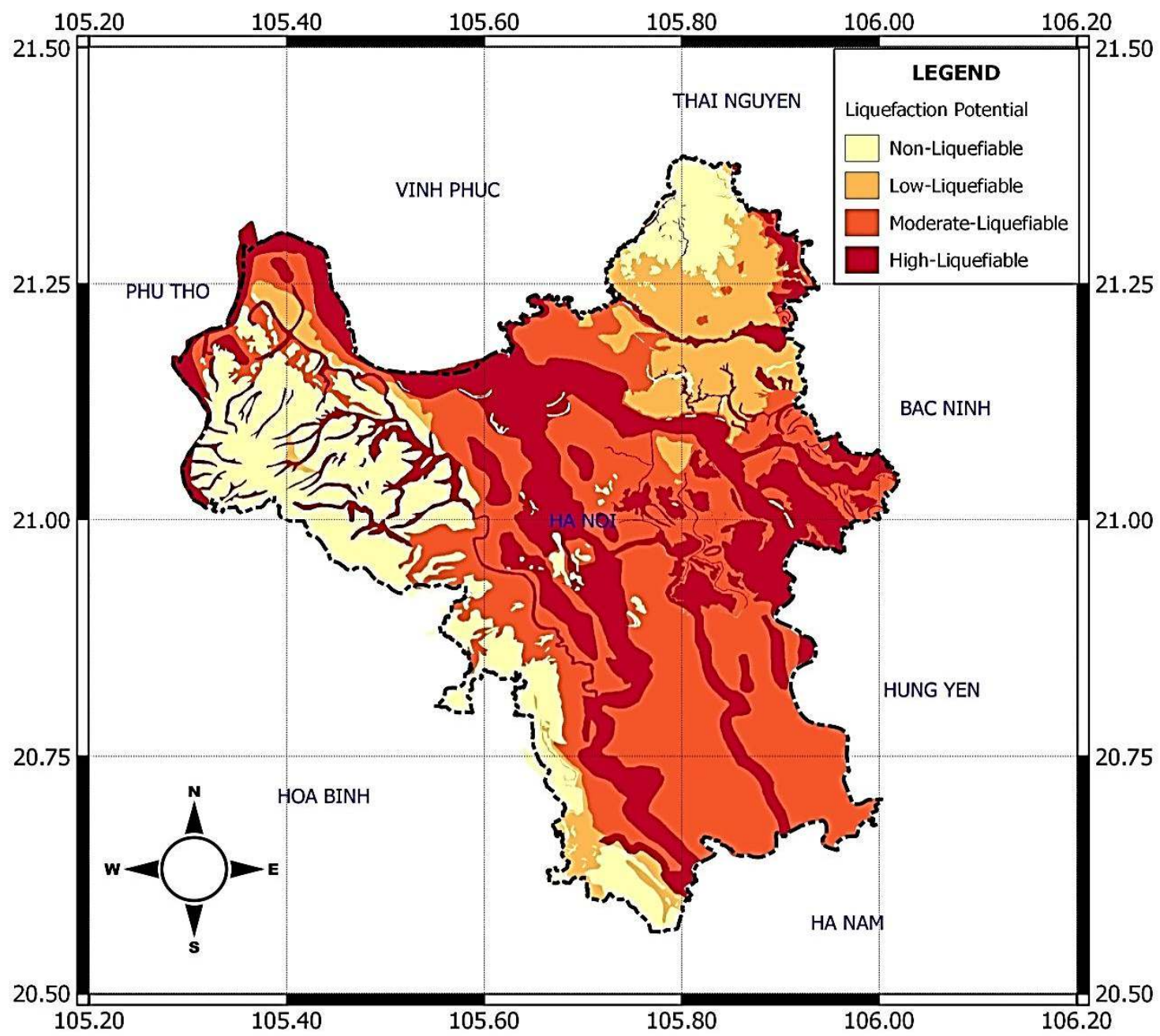

Figure 4. Map of liquefaction susceptibility of Hanoi city obtained from the Iwasaki (1982) method

As can be seen in Figure 5, after integration of liquefaction susceptibility based on both geological and geomorphologic characteristics, moderate liquefaction susceptibility is still dominated by the entire Hanoi region. The equivalence in zoning shapes of the two maps in Figure 5 and Figure 3 can be explained by the weighting rule applied in compiling these maps. A slight difference between these maps is observed in the western suburb and in the northwestern part of the city, where the none-liquefiable zone in Figure 3 is less than the same zone in Figure 5. The difference between two maps in
Figure 5 and Figure 4 is considerable, where the zone with high liquefaction susceptibility in Figure 5 is much less in the area in compare with that zone in Figure 4. It should also be noted that, the use of the 1:320,000 scale geomorphologic map and the much bigger 1:25,000 scale engineering-geologic map leads to the different reliability of the two results. However, this fact does not affect the final results thanks to the weighting rule described above. In general, the geomorphologic characteristics clearly affect the liquefaction susceptibility in the areas with higher elevation, of denudation origin. 


\section{Conclusion}

In this paper, using published geologic and geomorphologic information of Hanoi (Dao Dinh Bac, 2010; Phan Trong Trinh, 2012, Vu Thanh Tam, 2014; Ngo Quang Toan, 2015), the ground liquefaction potential have been assessed using the methods proposed by Youd and Perkins (1978) and Iwasaki (1982). The obtained thematic maps of liquefaction susceptibility based on the subsurface lithology characteristics (Figure 3) and geomorphologic characteristics (Figure 4) are assigned with the weighting values of $60 \%$ and $40 \%$, respectively and integrated into a final GIS map of liquefaction susceptibility of Hanoi city (Figure 5).

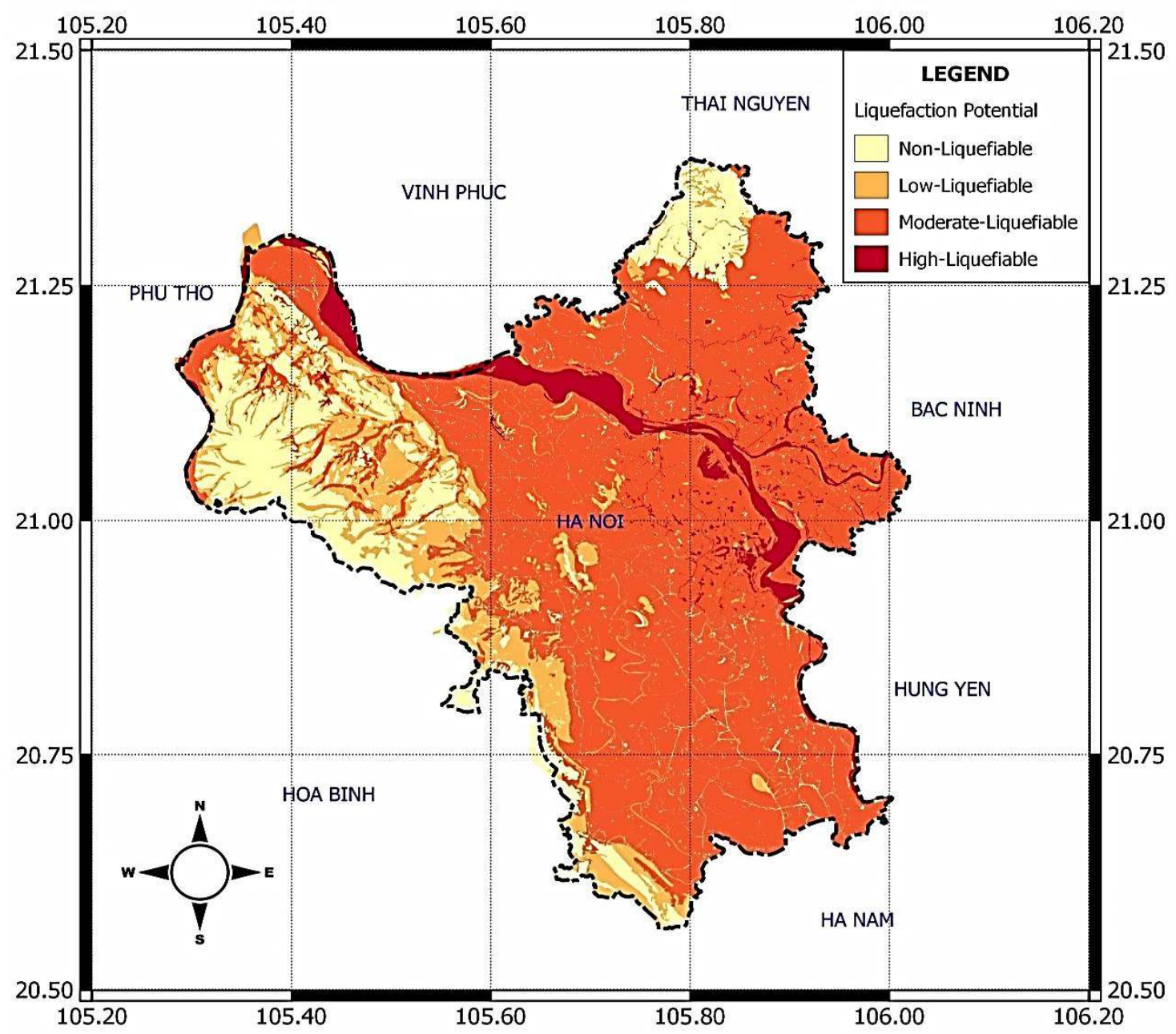

Figure 5. Map of liquefaction susceptibility of Hanoi city based on the geologic and geomorphologic characteristics

The resulting map shows that the liquefaction susceptibility of Hanoi city is classified into four categories: high, moderate, low susceptibility to liquefaction and not liquefiable. The highest potential of liquefaction is observed in a zone spreading along the ancient
Red river's bed and some places in the downtown area, which are the Late-Holocene sedimentary deposits comprise sand, fine sand mixed with dark gray clayish silt-bearing plant humus, brownish gray mud with the high level of ground water. The zone contains 
such geomorphologic units as rivers, lakes, swamps and low alluvial plains. The zone with the moderate potential of liquefaction occupies the majority of the city's area, stretching along both sides of the Red river's bank, comprise such petrographic units as clay, clayish silt, sand, sandy silts of Holocene age and such geomorphologic units as plains of the river and marine origin and alluvial plains. The northwestern and northeastern mountainous areas of Hanoi known as the Soc Son, Chan Chim and Ba Vi are not liquefiable or having low liquefaction susceptibility, which comprise claystone, sandstone, hard rock of denudation origin. It is worth emphasizing that the buildings and pipelines in the zone with high and moderate potential of liquefaction are vulnerable to damage due to horizontal displacement during earthquakes.

Soil liquefaction is a major cause of damage during earthquakes. The liquefaction susceptibility map displays the zones with liquefaction potential, or the risk of initiation of liquefaction during future earthquakes and can be used as the input for calculation and mapping of liquefaction hazard map of the study area. Being a qualitative function of geologic and geomorphologic characteristics, the liquefaction susceptibility is independent with the seismicity of a certain region. Therefore, the use of other region-dependent elements as seismicity, geotechnical information is considered as the next step for the research of liquefaction assessment.

The obtained liquefaction susceptibility map provides useful information for the urban seismic hazard assessment and seismic risk management, mitigation and reduction for Hanoi city. The map can be used as the reference for civil and geotechnical engineers for antiseismic design of the new constructed buildings or restoration of old and damaged buildings. In general, the obtained liquefaction susceptibility map displays a portrayal of the liquefaction susceptibility of the Hanoi city as the preliminary information for the regional research.

\section{References}

Bird JF, Bommer JJ, 2004b. Earthquake Losses due to Ground Failure. Submitted to Engineering Geology, 75(2), 147-179.

Bird Juliet F, Bommer Julian J., 2004a. Evaluating earthquake losses due to ground failure and identifying their relative contribution (Paper no. 3156). In Proceedings of the $13^{\text {th }}$ world conference on earthquake engineering, Vancouver, B.C., Canada, august 1-6.

Bui Van Duan, Nguyen Cong Thang, Nguyen Van Vuong, Pham Dinh Nguyen, 2013. The magnitude of the largest possible earthquake in the Muong LaBac Yen fault zone. J. Sci. of the Earth, 35(1), 5359.

Dao Dinh Bac, Dang Van Bao, 2010. Geomorphologic characteristics, the ancient river beds system of the capital city and their values to the development of the Thang Long - Hanoi. International Workshop commemorating the 1000 years of Thang Long, Hanoi. Vietnam national University, Hanoi.

Ganapathy, G. P., Rajawat, A. S., 2012. Evaluation of liquefaction potential hazard of Chennai city, India: using geological and geomorphological characteristics. Natural hazards, 64(2), 1717-1729.

Goyal, A., Sinha, R., Chaudhari, M. and Jaiswal, K., 2001. Performance of Reinforced Concrete Buildings in Ahmedabad during Bhuj Earthquake January 26, 2001. Workshop on Recent Earthquakes of Chamoli and Bhuj: Volume I, Roorkee, India, May 24-26.

Iwasaki, T., Tokida, K., Tatsuoka, F., Watanabe, S., Yasuda, S., Sato, H., 1982. Microzonation for soil liquefaction potential using simplified methods. In Proceedings of the $3^{\text {rd }}$ international conference on microzonation, Seattle, 3, 1310-1330.

Kuribayashi E., Tatsuoka, F., 1975. Brief review of liquefaction during earthquake in Japan," Soils and Foundations, 15(4), 81-92.

Lew M, Naeim F, Huang SC, Lam HK, Carpenter LD, 2000. Geotechnical and geological effects of the 21 September 1999 Chi-Chi earthquake, Taiwan. Structural Design of Tall Buildings, 9, 89-106.

National Research Council, 1985. Ishihara 1985. Liquefaction of Soils During Earthquake, National Academy press, 240, p.34. 
Nguyen Hong Phuong (Project Manager), 2002. Study of seismic risk of Hanoi city. Project code 01C04/09-2001-2. Institute for Marine Geology and Geophysics, VAST.

Nguyen Hong Phuong (Project Manager), 2007. Application of GIS technology to Development of a model for seismic risk analysis for Hanoi city. Institute for Marine Geology and Geophysics, VAST.

Nguyen Hong Phuong (Project Manager), 2014. Estimation of Site Effects and Assessment of Urban Seismic Risk for Hanoi city. National Scientific Research Project Final report, Institute of Geophysics, VAST.

Nguyen Hong Phuong and Pham The Truyen, 2014. Probabilistic seismic hazard assessment for South Central Vietnam. J. Sci. of the Earth, 36(4), 451461.

Phan Trong Trinh, Hoang Quang Vinh, Nguyen Van Huong, Ngo Van Liem, 2013. Active fault segmentation and seismic hazard in Hoa Binh reservoir, Vietnam. Cent. Eur. J. Geosci, 5(2), 223-235.

Phan Trong Trinh, Ngo Van Liem, Nguyen Van Huong, Hoang Quang Vinh, Bui Van Thom, Bui Thi Thao, Mai Thanh Tan, Nguyen Hoang, 2012. Late Quaternary tectonics and seismotectonics along the Red River fault zone, North Vietnam. Earth-Science Reviews 114, 224-235.

Susumu Yasuda, Nozomu Yoshida, Hiroyoshi Kiku, Hidenori Abo, and Masato Uda, 2001. Analyses of Liquefaction-Induced Deformation of Grounds and Structures by a Simple Method (March 26). Interna- tional Conferences on Recent Advances in Geotechnical Earthquake Engineering and Soil Dynamics, p.27.

http://scholarsmine.mst.edu/icrageesd/04icrageesd/s ession04/27.

Updike, R. G., Egan, J. A., Moriwaki, Y., Idriss, I. M., Moses, T. L., 1988. A model for earthquake-induced translatory landslides in Quaternary sediments. Geological Society of America Bulletin, 100(5), 783-792.

$\mathrm{Vu}$ Thanh Tam (Project Manager), 2014. Study and propose a reasonable threshold for preventing the subsidence caused by ground water exploitation, pilot application for downtown area of the Hanoi city. Final report of the Scientific research and technology development Project, National Center for water resource planning and investigation. Ministry of Natural Resources and Environment.

Youd T. L., 1993. Liquefaction, ground failure and consequent damage during the 22 April 1991 Costa Rica earthquake. Abridged from EERI Proceedings: U.S. Costa Rica Workshop, http://nisee.berkeley.edu/costarica/

Youd T. L., and Hoose S.N., 1977. Liquefaction Susceptibility and Geologic Setting, Proceedings, $6^{\text {th }}$ World Conference on Earthquake Engineering, New Delhi, India, 6, 37-42.

Youd T. L., and Perkins D. M., 1978. Mapping liquefaction-induced ground failure potential. Journal of the Geotechnical Engineering Division, ASCE, 104, GT4, 433-446. 